\title{
The Effect of Post-Teaching Activity Type on Vocabulary Learning of Elementary EFL Learners
}

\author{
Karim Sadeghi ${ }^{1} \&$ Faranak Sharifi $^{1}$ \\ ${ }^{1}$ Urmia University, Urmia, Iran \\ Correspondence: Faranak Sharifi, Urmia University, Urmia, Iran. E-mail: frnksharifi@gmail.com
}

Received: August 13, 2013 Accepted: September 3, 2013 Online Published: October 10, 2013

doi:10.5539/elt.v6n11p65 URL: http://dx.doi.org/10.5539/elt.v6n11p65

\begin{abstract}
Considering the significant role of vocabulary in learning a language, and teachers' great responsibility in providing opportunities to facilitate this learning, many studies have focused on the best means of achieving a good knowledge of vocabulary. This study set out to investigate the effect of four post-teaching activities, namely game, narrative writing, role-play, and speaking tasks on vocabulary gain of elementary Iranian EFL learners across gender. The sample in the study was composed of 111 elementary adult EFL learners assigned into four experimental groups for females and four experimental groups for males as well as two control groups one for each gender, at AVA Talk Institute, Urmia, Iran. Successive to the pre-test, which was meant to measure the learners' prior knowledge of the target words, learners were asked to carry out the required tasks using the words they were provided with. The results of two-way ANOVA analysis indicate statistically significant main effects for vocabulary learning across different activity types with role-play leading to the highest vocabulary gain $(M=19.27, S D=3.70)$. Moreover, the gender of participants has a significant $[F(1,168)=28.40, p=.000]$ impact upon the vocabulary learning of the participants, with female learners outperforming their male peers. The results of the study have implications for EFL teachers and provide them with new insights into implementing task-oriented activities for better retention of vocabulary.
\end{abstract}

Keywords: games, narrative writing, role-play, speaking tasks, vocabulary retention

\section{Introduction}

\subsection{Learning Vocabulary}

It has long been known that vocabulary is a central component of a language and all language learners are aware of the fact that limitations in their vocabulary knowledge affect their communication skills. Communication breaks down when people do not know and do not use the right words and it stops when people lack the necessary words (Allen, 1983).

Taking into account the communicative power of vocabulary, language teachers make every endeavor to facilitate the learning process. In recent years, there has been a trend to shift the focus away from the teacher and make students more responsible for their own learning. That is, attempts have been made to design more student-centered activities for intended lexical input. Furthermore, although a teacher's explanations and examples may seem of great help in vocabulary learning, they are unlikely to become a long-term part of the learner's vocabulary store. Presenting words is only the tip of the iceberg. Vocabulary learning is effective when it entails active engagement in learning tasks. To ensure that learners get to know the new words, they will need plentiful opportunities to engage with the words and to put them to work in a variety of contexts (Thornbury, 2002). That is, the teacher's responsibility does not only lie in helping learners meet some new words, but also in making sure that those new words are learned, stored, and recalled. In other words, the learner needs not only to learn a lot of words, but to remember them as well.

Therefore, in promoting vocabulary learning, there is a need for an approach, in which all learners are required to make contributions. Most importantly, language students need the willingness to be active learners over a long period of time; otherwise, there will be a low chance of retaining vocabulary, regardless of the quality of instruction. Moreover, in order to learn and remember new words, learners should take part in different task-based activities such as conversation making, a describing exercise or guessing task. Such activities may 
include vocabulary games, role-plays, narrative writing, or even speaking tasks which especially focus on helping learners develop and use words in different contexts by making the lessons enjoyable.

Language teachers' main concern, therefore, is to ensure that what is taught will be permanently retained in long term memory. In fact, retrieving vocabulary is an effective way of learning. In other words, for acquisition to take place, language learners must work with a word or phrase many times. Despite the abundant number of methods and techniques proposed to help learners learn the new vocabulary items at instruction phase, less attention is paid to techniques which may help the retention of those items. Learners are usually left with a large number of items they are expected to recall after the initial instruction on definition and use of the words, most of which fade away by the passage of time. Although research (Schouten-van Parreren, 1989; Lee, 2003; Scott \& Nagy, 2004; Schmitt, 2008; Shintani, 2011;) has been carried out on vocabulary teaching methods for language learners, research pertaining to providing opportunities to use new vocabulary in authentic contexts is limited. Thus, to contribute to the thriving body of research in this field, this study sought to investigate activities which can help encourage the above mentioned processes to occur and which can facilitate learning vocabulary. It aimed to examine the effect of narrative writing, games, role-play and other speaking activities on the vocabulary learning of elementary EFL students in order to find out which activity would be of more help in the vocabulary learning process.

\subsection{Review of the Literature}

Vocabulary learning is a memory task, but it also involves creative and personalized use, that is, learning and using (Thornbury, 2002). Nation (1982) argues that meeting a word in a number of different environments will help learners grasp its full meaning. Moreover, it will help the learner realize what part of speech the word is, that is, if it is a noun or a verb, etc. He further highlights the importance of progressive fashion that goes beyond rote memorization in vocabulary learning. Students need to practice regularly what they have learnt; otherwise, the material will fade away. This means that language teachers' great responsibility is to create opportunities through which learners are exposed to the new items.

Elley (1989) claims that repeated exposure to new vocabulary in a meaningful context accounted for the vocabulary gains for his subjects. Schmitt (2008) argues that the most effective way of improving incidental learning is by reinforcing it afterwards with intentional learning tasks.

This implies that different teaching approaches may be appropriate at different stages of acquisition of an item. As Schmitt (2008) has demonstrated, at the beginning, an explicit approach which focuses directly on establishing the form-meaning link can be most effective, while later, the exposure approach can be most beneficial in enhancing contextual knowledge. Richardson (1997) wrote:

"The traditional approach to teaching - the transmission model - promotes neither the interaction between prior and new knowledge nor the conversations that are necessary for internalization and deep understanding. The information, if acquired at all, is usually not well integrated with other knowledge held by the students" ( $p .3)$.

Scott and Nagy (2004) explain that good word instruction takes place in classrooms where lessons pay special attention to specific words and word-learning strategies, where learners are provided with ample opportunities to talk about words, and there are many occasions for applying the taught material into content-rich texts with motivating purposes. For this means, the researchers of the present study opted for four different activities namely, game, role-play, narrative writing and speaking task.

\subsubsection{Narrative Writing}

The importance of writing good quality narrative has long been recognized in the field of education (Miller \& McCardle, 2011). Muncie (2002) points out that writing in context is a tool for general second language improvement provided that it pays special attention to vocabulary use. Furthermore, students begin to consider the relevancy of learning language in relation to the amount of enjoyment and interest they receive through narrative writing.

Previous studies have assessed effects of writing target words in sentences or compositions. Several studies (Hulstijn \& Laufer, 2001; Laufer, 2003) have drawn the conclusion that using new words to write a composition results in better word learning compared to reading a text for comprehension, regardless of whether new words are glossed or looked up. Hulstijn and Laufer (2001) found that learners writing compositions remembered a set of target words better than those who saw the words in a reading comprehension task, and learners who supplied missing target words in gaps in the reading text remembered more of those words than learners who read marginal glosses. In both comparisons, the 'better learning' case had higher involvement according to Hulstijn and Laufer's scheme. 
The results of the study carried out by Lee (2003) on English as a Second Language (ESL) learners' vocabulary use in writing and the effects of explicit vocabulary instruction indicated that $13.19 \%$ of recognized target vocabulary was productive in writing after reading instruction and comprehension exercise and before target vocabulary instruction. This increased significantly to $63.62 \%$ after target vocabulary instruction and productive use of newly learned vocabulary. Thus, newly learned productive vocabulary increased significantly in an immediate writing task after explicit instruction

\subsubsection{Role-Play}

Needless to say, a problem in many ESL/EFL classes is how to provide opportunities for learners to engage in meaningful conversation practice. Conversational activities are often difficult to arrange in large classes and there may be no obvious motivation for learners to speak to each other in English (Richards, 1985).

According to Sasaki (1998), role plays are regarded as simulating more authentic situations. Dent-Young (1977) states, "Role-play exercises are essentially a means of bringing a broad range of experience into a narrow classroom learning situation, through stimulation of the learner's imagination and his interaction with other learners" (p. 61).

Bredemeier and Greenblat (1981) concluded that role plays are effective means of teaching, not better than other instructional methods on learning the subject though. However, they are more effective as aids to retaining the learned material and in instilling a positive attitude about the subject matter. The outcome of the research conducted by Liu and Ding (2009) on the effect of role-play in language teaching shows there are four crucial factors for its success: "the topic chosen should be real and relevant; the teacher needs to 'feed-in' the appropriate language; correct errors in a proper way; part of a teacher's role is being a facilitator, a spectator or a participant" (p. 140).

\subsubsection{Games}

A factor in students' willingness to allocate their time and effort is their interest and motivation (Sideridis, Mouzaki, Simos, and Protopapas, 2006). Word games are obviously helpful because they can make the student feel that certain words are important and necessary because without those words the object of game cannot be achieved. By bringing fun to language classrooms, games help create a relaxed atmosphere, which plays a role in students' remembering things faster and better (Wierus and Wierus, 1994). Lee (1979) holds that most language games make learners use the language instead of thinking about learning the correct forms.

Malone and Lepper (1987) have claimed that individuals wish for an optimal level of challenge. For them, we are challenged by activities that are neither too easy nor too difficult to perform. The optimal level can be obtained when there are clearly specified goals. Malone and Lepper suggest that factors such as difficulty levels, multiple goals, and a certain amount of informational ambiguity are required by games. Finally, goals must be meaningful to the individual. The addition of word games to vocabulary instruction can boost student motivation and help them engage with vocabulary cognitively, which results in improvements in acquisition rates and deeper levels of processing (Charlton, Williams, \& McLaughlin, 2005).

Charlton et al. (2005) identified one means of increasing student motivation to actively participate in word study activities as disguising instruction as play by using word games. In their study, Charlton et al. noted that word games provide repeated exposure to the target vocabulary words in an intrinsically and extrinsically motivating context which facilitate learning. Word games can provide a reason and a context for students to learn and actively use the target vocabulary. Further support comes from Wells and Narkon (2011) who maintained that vocabulary games can be designed to supplement teacher directed instruction and support student comprehension and mastery of important content.

In his research on the effect of games on EFL learners' vocabulary learning strategies, Sorayaie Azar (2012) found that games have been shown to have advantages and effectiveness in learning vocabulary in different ways. First, games facilitate the retention of new words by bringing in relaxation and fun to learners. Second, they usually involve friendly competition and keep learners interested.

\subsubsection{Speaking Tasks}

Speaking tasks such as split information tasks, class presentations, ranking activities, and problem solving discussions are not usually thought of as having vocabulary learning goals. One of the reasons for this might be the fact that planning vocabulary learning as a part of a syllabus using productive, unpredictable activities in the discussion group seems very difficult. Drawing on recent research, it can be found out how a vocabulary learning goal can be effectively designed into many speaking activities. Norris (1991) provides an overview of interactive discussions regarding target vocabulary and maintains that discussions include identifying what the word means 
(semantics), how the words is used in sentences (syntax), how the word is divided into minimally significant units of meaning (morphology), and how the words can be used in a communicative context (pragmatics).

Current emphasis on oral acquisition in L2 research highlights the importance of learner interaction and negotiation (de la Fuente 2002). Chen and Graves (1998) suggest asking a discussion question to promote student involvement, followed by a brief overview of any material. In his study on vocabulary learning and speaking activities, Newton (1993) found that when learners discussed the meanings of words from the worksheet with each other, the majority of words discussed resulted in useful and accurate information about the words. In a different study on 45 Vietnamese learners, Huong (2006) sought to examine the effect of speaking tasks on vocabulary learning in group work. Over a period of three months every member of the class was audio-recorded and they all had to speak English. Each session all groups discussed the same topic. However, the group discussions included taking meaning from a written textbook, and it was not restricted to oral discussion. Setting time constraint as one of the rules, members were to take turns to speak, and therefore, opportunity was provided for all the members of the group to contribute. Through the examination of journal entries and interviews, Huong detected three categories: (1) the students provided examples of the words that they had learned; (2) joint learning of vocabulary in which the students shared their knowledge of words; and (3) collective memory in which group members through interaction helped other members in recalling and remembering words. The data from the transcription showed that when the students encountered new words, they usually asked others. Some students recalled their experience of learning vocabulary in the group work. Huong reported that the students perceived the importance of vocabulary in the process of using English and not only were they engaging with words, but they were also using each other's vocabulary knowledge.

As the review of literature reveals, recent developments in learning vocabulary provide new opportunities for the application of many activities into education. However, most language teachers or even material designers have doubts about using the right activity. The focus of the research in the area of vocabulary learning should be not only on the instruction phase, but also on the activities following the instruction to help the retention of the new material. However, as it has already been stated, the type of the activity, the way it is applied, and the people who are subject to such activities are of great importance in this area. Although a large body of work (Foil \& Alber, 2002; Muncie, 2002; Lee, 2003; Barcroft, 2004; Charlton, B., Williams, \& McLaughlin, 2005; Folse, 2006) has investigated the role of different activities, namely writing tasks, and games in the retention of newly-learned vocabulary items in ESL/EFL classrooms, there is a dearth of research assessing the effectiveness of speaking tasks, and role-plays in this regard or even one activity's superiority over the other, a gap which this study intends to bridge.

Research in learning vocabulary in a second/foreign language is well documented. However, no study has investigated the degree of the effectiveness of different post-teaching activity types in terms of learning vocabulary.

\section{Methodology}

\subsection{Participants}

One hundred and sixteen adult Iranian elementary EFL learners (at the ages of 16-32), comprising 47 males and 64 females at a language school were chosen as the participants of the study. Female and male participants were separately divided into 10 intact classes, 8 of which were considered as experimental groups and 2 as control groups. In order to make sure that all the participants, taking BLC 5 (Beginner Language Course) classes in the language school, had an elementary level of proficiency in English, KET (Key English Test) produced by Cambridge University, was administered. Those participants whose scores were more than 2 Standard Deviation (SD) above or less than $2 \mathrm{SD}$ below the mean $(\mathrm{M}=17.20)$ were considered as outliers and therefore eliminated from further analysis in the first place. Therefore, the results of the present study are based on the performance of one hundred and eleven participants.

\subsection{Instruments}

The following instruments were used in this study for data elicitation purposes.

In order to homogenize the participants in terms of their language proficiency, Cambridge Key English Test (KET) was utilized. KET, which uses language from real life situations and covers four language skills, that is, reading, writing, listening and speaking, is the first-level Cambridge ESOL (English for Speakers of Other Languages) exam designed for adult learners. All the four skills include a range of tasks that assess the ability to use English. Paper 1, which is devoted to Reading and Writing skills, consists of 9 parts and 56 questions, and paper 2, the listening section, includes 5 parts and 25 questions. The types of exercises are: multiple-choice, 
gap-filling, comprehension questions, word completion and matching. The texts are either monologues or dialogues, including interviews, discussions, telephone conversations and messages.

The next data elicitation tool utilized in the study was a pre-test, consisting of 28 multiple-choice items devised by the researchers to measure the participants' existing lexical knowledge before the treatment was employed. All the questions were devised based on the content of the course book (Touchstone 2 by Michael McCarthy, Jeanne McCarten and Helen Sandiford, 2005) and one vocabulary book (Vocabulary in Use, Pre-intermediate and Intermediate by Stuart Redman, 2003) covered during the term. Faulty items were revised, substituted or removed through item analysis and after pilot testing and revision of the questions by an expert.

In addition, since all treatment groups required a different form of activity, each group was provided with various cards or handout. Each card or handout, prepared by the researchers, contained instructions on how to carry out the activity as well as a series of the target vocabulary which the participants needed to use to write a story, start a discussion, play a game or act out a role-play. To determine any possible effect of the treatments and to measure the participants' lexical gain at the end of the term, a post-test, which was parallel with the pre-test and contained 28 multiple choice items, was administered to all the treatment as well as the control groups the session before the final examination.

\subsection{Procedure}

This study sought to determine the possible effect of different post-teaching activity types on the vocabulary gain of beginner Iranian EFL learners across gender through employing the following procedures:

At the outset of the research, to guarantee the participants' homogeneity, Cambridge Key English Test (KET) was administered to all the treatment and control groups. Successive to homogenizing the participants, the 10 intact classes, each containing 10-15 students, were randomly assigned into eight experimental and two control groups. Four of the experimental groups belonged to males and four to females with one male and one female group assigned as control groups. The pretest which contained multiple choice questions on the vocabulary items of the content of the initial unit of the course book as well as 4 units of Vocabulary in Use pre-intermediate and intermediate by Stuart Redman (2003) was administered on the fourth session. Hence, all treatments started in the fifth session of the term and a total number of 9 sessions were allocated to each treatment in view of the fact that all the treatments were to have been completed by the end of session 13 out of 16 sessions that constitute a term in the language school. Successive to the completion of all the activities required for the study, the post-test, parallel to the pre-test, was administered on session 14.

\subsection{Data Analysis}

The research question of whether implementing different vocabulary-based post-teaching activity types yields distinctive vocabulary learning outcomes across gender was investigated by analyzing the pre-test and post-test results quantitatively. The study also sought to determine which activity would yield more effective results. The data was analyzed using two-way ANOVAs for pre-test and post-test after feeding them to the SPSS (Statistical Package for Social Sciences) software version 19.

\section{Results and Discussion}

The descriptive statistics for the differences in the vocabulary learning of male and female participants in the pre-test and post-test results are reported in Table 1.

Table 1. Descriptive statistics for pre- and post-test results across gender

\begin{tabular}{lllccc}
\hline Gender & Activity & Time & Mean & $\begin{array}{c}\text { Std. } \\
\text { Deviation }\end{array}$ & N \\
\hline Female & Game & Pre & 18.0000 & 4.86172 & 12 \\
& & Post & 19.6667 & 5.12274 & 12 \\
& Total & 18.8333 & 4.95779 & 24 \\
& Role play & Pre & 20.0000 & 2.21108 & 10 \\
& & Post & 22.3000 & 1.88856 & 10 \\
& Total & 21.1500 & 2.32322 & 20 \\
& Speaking & Pre & 18.4000 & 5.34255 & 15 \\
& & Post & 20.6000 & 5.99762 & 15 \\
\hline
\end{tabular}




\begin{tabular}{|c|c|c|c|c|c|}
\hline & & Total & 19.5000 & 5.69180 & 30 \\
\hline & \multirow[t]{3}{*}{ Story } & Pre & 15.3333 & 4.32049 & 15 \\
\hline & & Post & 16.6667 & 5.66527 & 15 \\
\hline & & Total & 16.0000 & 4.99655 & 30 \\
\hline & \multirow[t]{3}{*}{ Total } & Pre & 17.7308 & 4.66575 & 52 \\
\hline & & Post & 19.5769 & 5.40641 & 52 \\
\hline & & Total & 18.6538 & 5.10999 & 104 \\
\hline \multirow[t]{15}{*}{ Male } & \multirow[t]{3}{*}{ Game } & Pre & 15.7000 & 4.83161 & 10 \\
\hline & & Post & 18.0000 & 4.92161 & 10 \\
\hline & & Total & 16.8500 & 4.89118 & 20 \\
\hline & \multirow[t]{3}{*}{ Role play } & Pre & 17.2500 & 3.62128 & 12 \\
\hline & & Post & 18.1667 & 4.36585 & 12 \\
\hline & & Total & 17.7083 & 3.95055 & 24 \\
\hline & \multirow[t]{3}{*}{ Speaking } & Pre & 10.8889 & 4.22624 & 9 \\
\hline & & Post & 12.0000 & 3.46410 & 9 \\
\hline & & Total & 11.4444 & 3.79198 & 18 \\
\hline & \multirow[t]{3}{*}{ Story } & Pre & 14.3333 & 5.09902 & 9 \\
\hline & & Post & 14.2222 & 6.30035 & 9 \\
\hline & & Total & 14.2778 & 5.56042 & 18 \\
\hline & \multirow[t]{3}{*}{ Total } & Pre & 14.7750 & 4.87004 & 40 \\
\hline & & Post & 15.8500 & 5.33277 & 40 \\
\hline & & Total & 15.3125 & 5.10297 & 80 \\
\hline \multirow[t]{15}{*}{ Total } & \multirow[t]{3}{*}{ Game } & Pre & 16.9545 & 4.87440 & 22 \\
\hline & & Post & 18.9091 & 4.98483 & 22 \\
\hline & & Total & 17.9318 & 4.97154 & 44 \\
\hline & \multirow[t]{3}{*}{ Role play } & Pre & 18.5000 & 3.30584 & 22 \\
\hline & & Post & 20.0455 & 3.99377 & 22 \\
\hline & & Total & 19.2727 & 3.70646 & 44 \\
\hline & \multirow[t]{3}{*}{ Speaking } & Pre & 15.5833 & 6.11425 & 24 \\
\hline & & Post & 17.3750 & 6.64512 & 24 \\
\hline & & Total & 16.4792 & 6.38145 & 48 \\
\hline & \multirow[t]{3}{*}{ story } & Pre & 14.9583 & 4.54427 & 24 \\
\hline & & Post & 15.7500 & 5.89952 & 24 \\
\hline & & Total & 15.3542 & 5.22469 & 48 \\
\hline & \multirow[t]{3}{*}{ Total } & Pre & 16.4457 & 4.95333 & 92 \\
\hline & & Post & 17.9565 & 5.65863 & 92 \\
\hline & & Total & 17.2011 & 5.35696 & 184 \\
\hline
\end{tabular}

As is observed in Table 1, both male and female participants have a better vocabulary performance in the post-teaching activities compared to the pre-teaching activities.

However, in order to have a detailed analysis of the exact points of differences, a two-way analysis of variance was run, the results of which are illustrated in Table 2. 
Table 2. Two-way analysis of variance (ANOVA) results for vocabulary performance

\begin{tabular}{lcccccc}
\hline Source & $\begin{array}{c}\text { Type IV Sum } \\
\text { of Squares }\end{array}$ & Df & Mean Square & F & Sig. & $\begin{array}{c}\text { Partial Eta } \\
\text { Squared }\end{array}$ \\
\hline Corrected Model & $1466.465^{\text {a }}$ & 15 & 97.764 & 4.339 & .000 & .279 \\
Intercept & 51042.001 & 1 & 51042.001 & $2.265 \mathrm{E} 3$ & .000 & .931 \\
gender & 640.037 & 1 & 640.037 & 28.408 & .000 & .145 \\
activity & 548.768 & 3 & 182.923 & 8.119 & .000 & .127 \\
time & 95.040 & 1 & 95.040 & 4.218 & .042 & .024 \\
gender * activity & 289.693 & 3 & 96.564 & 4.286 & .006 & .071 \\
gender * time & 7.463 & 1 & 7.463 & .331 & .566 & .002 \\
activity * time & 11.765 & 3 & 3.922 & .174 & .914 & .003 \\
gender * activity * time & 7.925 & 3 & 2.642 & .117 & .950 & .002 \\
Error & 3785.094 & 168 & 22.530 & & & \\
Total & 59693.000 & 184 & & & & \\
Corrected Total & 5251.560 & 183 & & & & \\
\hline R Squar & & & &
\end{tabular}

R Squared $=.279$ (Adjusted R Squared $=.215$ )

The results of two-way ANOVA applied to post-test scores indicate statistically significant main effects for vocabulary learning across different activity types $[\mathrm{F}(3,168)=8.11, \mathrm{p}=.000]$. The results of descriptive statistics show that with respect to different pre- and post-teaching activities, participants have higher vocabulary achievement in the role play activities $(\mathrm{M}=19.27, \mathrm{SD}=3.70)$. Table 1 also indicates statistically significant main effects for the time of teaching $[\mathrm{F}(1,168)=4.21, \mathrm{p}=.042]$ such that better performances are noticed in the post-teaching activities $(\mathrm{M}=17.95, \mathrm{SD}=5.65)$ rather than pre-teaching tasks $(\mathrm{M}=16.44, \mathrm{SD}=4.95)$. Moreover, the gender of participants, according to Table 1 has a significant $[F(1,168)=28.40, p=.000]$ impact upon the vocabulary learning of participants, with female learners $(\mathrm{M}=18.65, \mathrm{SD}=5.10)$ outperforming their male peers $(\mathrm{M}=15.31, \mathrm{SD}=5.10)$ with the effect size of 145 provided in the column Partial Eta Squared. Results of the above Table also indicate the interaction effects of different variables, according to which only gender and activity types have a shared influence upon the vocabulary achievement of participants $[\mathrm{F}(3,168)=4.28, \mathrm{p}=.006]$. Also, the adjusted R squared below the table shows that the participants' pre- and post-task performance, gender, and their interaction effects could explain 0.21 percent of the overall variation in the dependent variable.

In addition, post-hoc comparisons using the Tukey test (see Table $3 \& 4$ ) indicate that the mean score for the game-based activity $(\mathrm{M}=17.93)$ is significantly different from the story-based activity group $(\mathrm{M}=15.35)$. The role-play group $(\mathrm{M}=19.27)$ differs significantly from both the speaking group $(\mathrm{M}=16.47)$ and the story group $(\mathrm{M}=15.35)$. The differences between the other activity groups do not reach statistical significance.

Table 3. Multiple comparisons between vocabulary-based activity types

\begin{tabular}{llccccc}
\hline \multirow{2}{*}{ (I) activity } & (J) activity & $\begin{array}{c}\text { Mean Difference } \\
(\mathrm{I}-\mathrm{J})\end{array}$ & Std. Error & Sig. & \multicolumn{2}{c}{$95 \%$ Confidence Interval } \\
\cline { 6 - 7 } game & role play & -1.3409 & 1.01198 & .548 & -3.9669 & 1.2851 \\
& speaking & 1.4527 & .99067 & .460 & -1.1181 & 4.0234 \\
& story & $2.5777^{*}$ & .99067 & .049 & .0069 & 5.1484 \\
& game & 1.3409 & 1.01198 & .548 & -1.2851 & 3.9669 \\
role play & speaking & $2.7936^{*}$ & .99067 & .027 & .2228 & 5.3643 \\
& story & $3.9186^{*}$ & .99067 & .001 & 1.3478 & 6.4893 \\
& game & -1.4527 & .99067 & .460 & -4.0234 & 1.1181 \\
\multirow{5}{*}{ speaking } & role play & $-2.7936^{*}$ & .99067 & .027 & -5.3643 & -.2228 \\
& story & 1.1250 & .96890 & .652 & -1.3892 & 3.6392 \\
\hline
\end{tabular}




\begin{tabular}{llllllc}
\hline \multirow{3}{*}{ story } & game & $-2.5777^{*}$ & .99067 & .049 & -5.1484 & -.0069 \\
& role play & $-3.9186^{*}$ & .99067 & .001 & -6.4893 & -1.3478 \\
& speaking & -1.1250 & .96890 & .652 & -3.6392 & 1.3892 \\
\hline
\end{tabular}

Base on observed means.

The error term Mean Square (Error0=22.53)

*.The mean difference is significant at the .05 level.

Table 4. Post-hoc Tukey test results for vocabulary performance

\begin{tabular}{ccccc}
\hline \multirow{2}{*}{ activity } & \multirow{2}{*}{$\mathrm{N}$} & \multicolumn{3}{c}{ Subset } \\
\cline { 3 - 5 } & & 1 & 2 & 3 \\
\hline Story & 48 & 15.3542 & & \\
Speaking & 48 & 16.4792 & 16.4792 & \\
game & 44 & & 17.9318 & 17.9318 \\
role play & 44 & & & 19.2727 \\
Sig. & & .668 & .460 & .530 \\
\hline
\end{tabular}

Means for groups in homogeneous subsets are displayed.

Based on observed means.

The error term is Mean Square (Error) $=22.530$.

Figures 1 and 2 below show the differences in the vocabulary performances of learners schematically.

\section{Estimated Marginal Means of vocabulary}

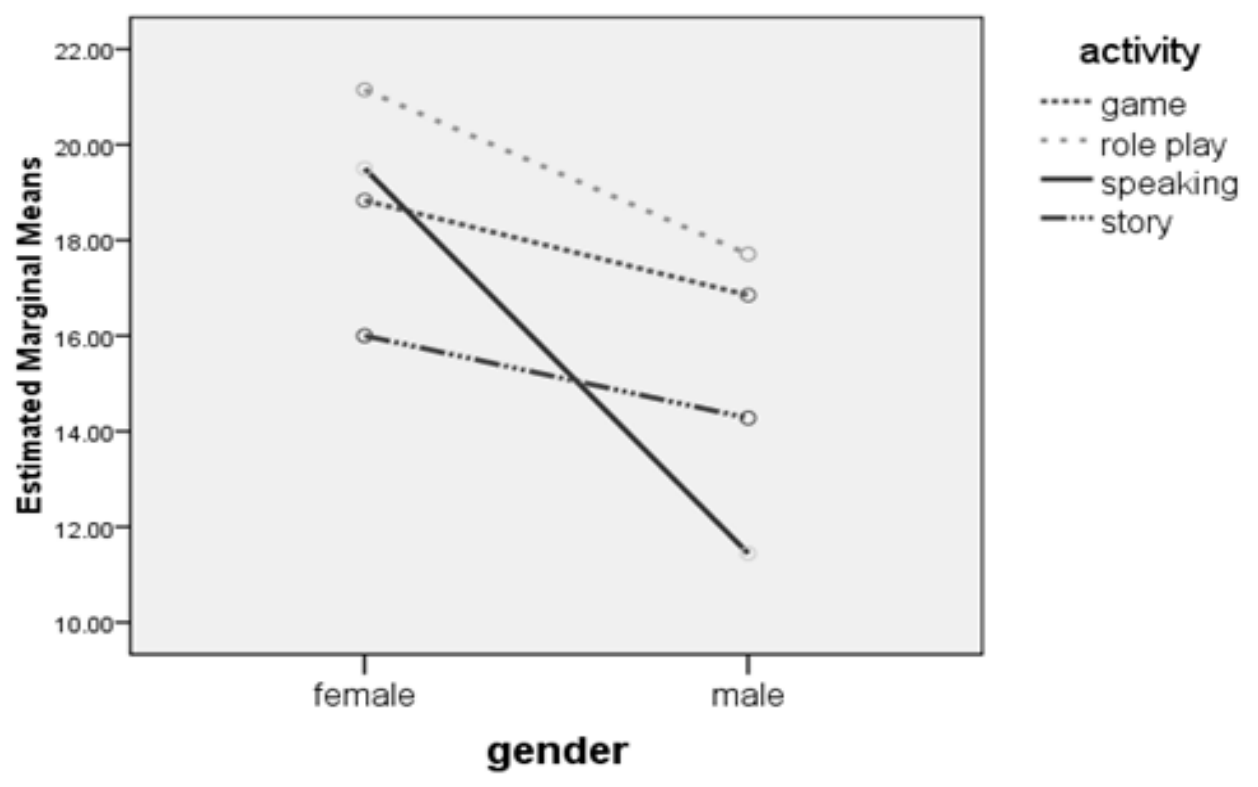

Figure 1. Differences between male and female participants' activity performance 


\section{Estimated Marginal Means of vocabulary}

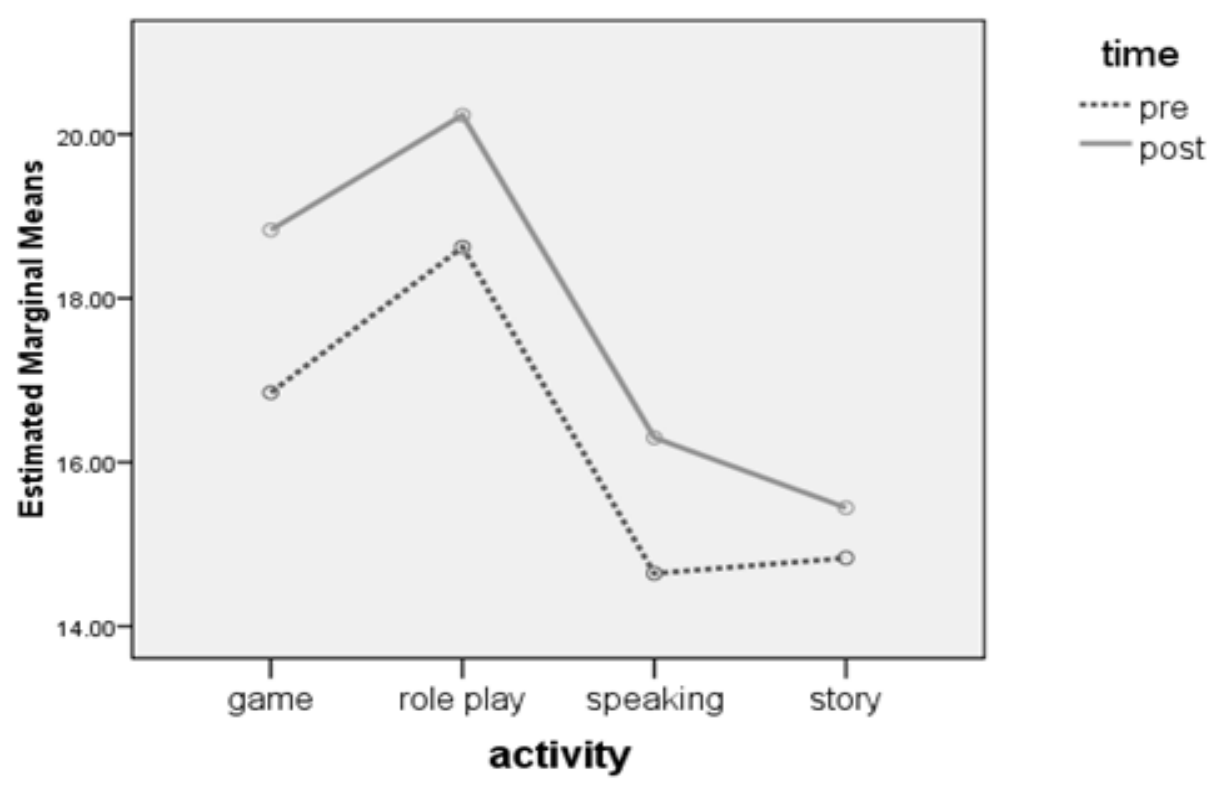

Figure 2. Differences between pre- and post-teaching activity performance

Generally, it can be concluded from the results of this study that exposure to certain vocabulary items through role-play activities results in better learning of those items. Moreover, after role-plays, games stand a good chance of being a useful tool through which vocabulary acquisition could be facilitated. While speaking tasks could be considered as another useful tool after game in vocabulary teaching to foreign language learners, the results of the study indicate that story writing activities are less effective in this regard.

The participants who received role-play as a means of practicing previously-learned vocabulary items, performed significantly better than other groups who received different types of treatment. Thus, it can be concluded that the findings of this study corroborate the findings of Bredemeier and Greenblat (1981) who concluded that role-plays could be effective means of teaching if used as aids to retain the learned material and, therefore, instilling a positive attitude about the subject matter. The results of the study are also in line with the findings of Alber and Foil (2003) who pointed that communicating messages to other people and discussions that focus on relating new words to students' personal experiences help link the new words to prior knowledge which in return influences the levels of comprehension.

The results of the post-test reveal that one of the experimental groups which received game as a treatment tended to retain the previously-learned vocabulary better than the next two groups which received speaking task and story writing as their treatment. Simply put, the analysis conducted in this study indicates that the use of games in EFL classes represents a promising activity rich in possibilities. Therefore, these finding are in line with Wierus and Wierus (1994) who believe that games create a relaxed atmosphere by bringing fun to language classes and help students remember things faster and better. Similarly, according to Charlaton et al. (2005) students' motivation to cognitively engage with vocabulary is boosted through the addition of word games and thus producing improvements in acquisition rates and deeper levels of processing. Furthermore, Berne and Blachowicz (2008) reported similar findings.

The results of the experimental group subjected to speaking task treatment revealed that although these activities yielded significant differences in the results of pre- and post-tests, they are not as effective as role-plays and games.

The effectiveness of speaking-based activities is consistent with the findings of Huang (2006). In his study, Huang reported that the students perceived the importance of vocabulary in the process of using English and not 
only were they engaging with words, but they were also using each other's vocabulary knowledge. Newton (1994) also maintains that in order to make it necessary for the learners to reuse the words that occurred in the textual input, retrieval can be designed into speaking activities. Furthermore, the interactive feature of most speaking tasks helps learn the material well. In his study, Huong (2006) showed that learning vocabulary is influenced not only by the capability of the peers within a group, but that group composition may have effects on different aspects of the practice of oral English.

Although the findings of the current study with regards to the implementation of story or narrative writing on vocabulary gain of EFL learners did not meet the researchers' early expectations, there is still a slight significant difference between the results of the pre- and post-test scores. Consistent with the results of this research is Pollock's statement (2003) that "When combined with contextually rich environments in vocabulary, thinking skills are very effective for realistic learning of language" (p. 6). Moreover, Hulstijn \& Laufer (2001) have drawn the conclusion that using new words to write a composition results in better word learning compared to reading a text for comprehension. This is also in line with the findings of Laufer (2003). Muncie's results (2002) also corroborate the findings of the current study as writing in context, with attention to vocabulary use, is considered as a tool for general second or foreign language improvement.

With regards to the effect of gender, the results of the two-way ANOVA revealed that there is a statistically significant difference between male and female language learners in terms of vocabulary gain through different activities with female learners outperforming their male peers. According to Chavez (2001) male students are often less engaged in the second language classroom. Male students do not interact with peers as much as female students do and are skeptical towards feedback received from peers. However, their learning outcome is not necessarily affected by this behavior. Female students tend to be more willing to communicate, and be engaged in discussions. It appears that male students do not take creative activities more seriously and tend to be less attentive during the activities.

\section{Conclusion}

In an attempt to gain insight into the effectiveness of different post-teaching activity types, namely games, role-plays, speaking tasks and story writing, this study launched and it was concluded that role-play leads to the highest vocabulary achievement compared to other activities. It was observed that the use of games, speaking tasks and story are respectively other means of post-teaching activities through which learning vocabulary could be facilitated. Moreover, gender was found to be an effective moderate variable in the performance of learners. Therefore, in order to have more productive classes, the amount of time devoted to the use of such activities should be taken into account. However, every study is subject to some limitations by virtue of possible methodological restrictions and practical realities and this study is no exception. Unequal number of participants in each group, administration of proficiency test in 3 sessions, and the particular proficiency level of the learners were among the limitations of the study. There are some recommended areas and possibilities for further research and future work indicated by present research. To open up new questions, the effect of the activities applied in this study could be further examined on language proficiency, grammar gain, or four skills of language learning, that is reading, writing, speaking, and listening.

\section{Acknowledgments}

The researchers owe their deepest gratitude to the students who were of great help throughout the study. Without their help, patience, and contribution, this study would not have been possible.

\section{References}

Alber, S. R., \& Foil, C. R. (2003). Drama activities that promote and extend your students' vocabulary proficiency. Intervention in School and Clinic, 39, 22-28.

Allen, V. French. (1983). Techniques in teaching vocabulary. Oxford: OUP.

Barcroft, J. (2004). Effects of sentence writing in L2 lexical acquisition. Second Language Research, 20 , 303-340. http://dx.doi.org/10.1191/0267658304sr233oa

Berne, J. I., \& Blachowicz, C. L. Z. (2008). What reading teachers say about vocabulary instruction: Voices from the classroom. The Reading Teacher, 62, 314-323. http://dx.doi.org/10.1598/RT.62.4.4

Bredemeier, M. E., \& Greenblat, C. S. (1981). The educational effectiveness of simulation games: A synthesis of findings. Simulation \& Games, 12, 307-332. http://dx.doi.org/10.1177/104687818101200304 
Charlton, B., Williams, R. L., \& McLaughlin, T. F. (2005). Educational games: A technique to accelerate the acquisition of reading skills of children with learning disabilities. International Journal of Special Education, 20, 66-72.

Chavez, M. (2001). Gender in the language classroom. Boston, MA: McGraw-Hill.

Chen, H. S., \& Graves, M. F. (1998). Previewing challenging reading selections for ESL students. Journal of Adolescent \& Adult Literacy, 41, 570-571.

De la Fuente, M. J. (2002). Negotiation and oral acquisition of Spanish L2 vocabulary: The roles of input and output in the receptive and productive acquisition of words. Studies in Second Language Acquisition, 24, 81-112. http://dx.doi.org/10.1017/S0272263102001043

Dent-Young, J. (1977). Role-play in language teaching. RELC Journal, 8, 61-68. http://dx.doi.org/10.1177/003368827700800106

Elley, W. (1989). Vocabulary acquisition from listening to stories. Reading Research Quarterly, 24, 174-187. http://dx.doi.org/10.2307/747863

Foil, C. R., \& Alber, S. R. (2002). Fun and effective ways to build your students' vocabulary. Intervention in School and Clinic, 37, 131-139. http://dx.doi.org/10.1177/105345120203700301

Folse, K. S. (2006). The effect of type of written exercise on L2 vocabulary retention. TESOL Quarterly, 40, 273-293. http://dx.doi.org/10.2307/40264523

Huang, L. P. H. (1996). Learning vocabulary in group work in Vietnam. RELC Journal, 37, 105-121. http://dx.doi.org/10.1177/0033688206063477

Hulstijn, J., \& Laufer, B. (2001). Some empirical evidence for the involvement load hypothesis in vocabulary acquisition. Language Learning, 51, 539-559. http://dx.doi.org/10.1111/0023-8333.00164

Laufer, B. (2003). Vocabulary acquisition in a second language: Do learners really acquire most vocabulary by reading? Some empirical evidence. The Canadian Modern Language Review, 59, 567-587. http://dx.doi.org/10.3138/cmlr.59.4.567

Lee, S. H. (2003). ESL learners' vocabulary use in writing and the effects of explicit vocabulary instruction. System, 31, 537-569. http://dx.doi.org/10.1016/j.system.2003.02.004

Liu, F., \& Ding, Y. (2009). Role-play in English language teaching. Asian Social Science, 5, 140-143.

Malone, T. W., \& Lepper, M. R. (1987). Making learning fun: A taxonomy of intrinsic motivations for learning. In R. E. Snow, \& M. J. Farr (Eds.), Aptitude, Learning and Instruction III: Conative and affective process analyses (pp. 223-253). Hilsdale, NJ: Erlbaum.

Miller, B., \& McCardle, P. (2011). Reflections on the need for continued research on writing. Reading and Writing, 24, 121-132. http://dx.doi.org/10.1007/s11145-010-9267-6

Muncie, J. (2002). Process writing and vocabulary development: Comparing lexical frequent profiles across drafts. System, 30, 225-235. http://dx.doi.org/10.1016/S0346-251X(02)00006-4

Nation, I. S. P. (1982). Beginning to Learn Foreign Vocabulary: A Review of the Research. RELC Journal, 13, 14-36. http://dx.doi.org/10.1177/003368828201300102

Newton, J. (1993). Task-based interaction among adult learners of English and its role in second language development. (Unpublished Ph.D. thesis), Victoria University of Wellington, New Zealand.

Norris, J. (1991). From frog to prince: Using written language as a context for language learning. Topics in Language Disorders, 12(1), 66-81. http://dx.doi.org/10.1097/00011363-199112010-00007

Pollock, E. J. (2003). Using mystery stories in the language classroom. Asian EFL Journal, 5, 3.

Richards, J. C. (1985). Conversational Competence through Role Play Activities. RELC Journal, 16, 82-100. http://dx.doi.org/10.1177/003368828501600107

Richardson, V. (1997). Constructivist teaching and teacher education: Theory and practice. In V. Richardson (Ed.), Constructivist teacher educational Building new understandings (pp. 3-14). Washington, DC: Falmer Press.

Sasaki, M. (1998). Investigating EFL students' production of speech acts: A comparison of production questionnaires and role plays. Journal of Pragmatics, 30, 457-484. http://dx.doi.org/10.1016/S0378-2166(98)00013-7 
Schmitt, N. (2008). Instructed second language vocabulary learning. Language Teaching Research, 12, 329-363. http://dx.doi.org/10.1177/1362168808089921

Schouten-Van Parreren, C. (1989). Vocabulary learning through reading: Which conditions should be met when presenting words in texts? AILA Review, 6, 75-85.

Scott, J. A., \& Nagy, W. E. (2004). Developing word consciousness. In J. F. Baumann, \& E. J. Kame'enui (Eds.), Vocabulary instruction: Research to practice (pp. 201-217). New York: Guilford.

Shintani, N. (2011). A comparative study of the effects of input-based and production-based instruction on vocabulary acquisition by young EFL learners. Language Teaching Research, 15, 137-158. http://dx.doi.org/10.1177/1362168810388692

Sideridis, G. D., Mouzaki, A., Simos, P., \& Protopapas, A. (2006). Classification of students with reading comprehension difficulties: The roles of motivation, affect, and psychopathology. Learning Disability Quarterly, 29, 159-180. http://dx.doi.org/10.2307/30035505

Sorayaie Azar, A. (2012). The effect of games on EFL learners' vocabulary learning strategies. International Journal of Basic and Applied Science, 1, 206-252.

Thornbury, S. (2002). How to teach vocabulary. Harlow: Pearson.

Wells, J. C., \& Narkon, D. E. (2011). Motivate Students to Engage in Word Study Using Vocabulary Games. Intervention in School and Clinic, 47, 45-49. http://dx.doi.org/10.1177/1053451211407493

Wierus, B., \& Wierus, A. (1994). Zagraj razem a nami. Czesc I. Jezyki obce w szkole, 218-222.

\section{Copyrights}

Copyright for this article is retained by the author(s), with first publication rights granted to the journal.

This is an open-access article distributed under the terms and conditions of the Creative Commons Attribution license (http://creativecommons.org/licenses/by/3.0/). 